\title{
TEST IMPACT: ENGLISH CERTIFICATION EXIT REQUIREMENTS IN TAIWAN
}

\author{
Yi-Ching Pan \\ National Pingtung Institute of Commerce, Taiwan
}

\begin{abstract}
In light of the importance of understanding the social impacts of test use, this paper synthesizes the opinions and surveys of a variety of stakeholders, including businesses, the government, administrators, educators and students, regarding the English exit requirements, as reported in major local newspapers during the last decade. It then constructs implications in terms of considerations for those involved in the establishment of the requirements and provides insights and suggestions for other stakeholders. By doing so, it is hoped that this study will be beneficial to those who are active in the fields of English teaching, policy-making and test development.
\end{abstract}

Key words: washback, test use, English certification tests, exit requirements

In Taiwan, English is taught as a foreign language (EFL) in a classroom environment. Following at least two years of English instruction in grades five and six, students receive another six years of English education before they attend colleges or universities, three years in junior high and three in high school. Students take two national exams: the Basic Competence English Test (BCET) to enter high school and either the University Entrance Examination (UEE) or College Entrance Examination (CEE) for institutes of higher education. The UEE was established as an admission criterion for high school students who wish to attend universities, whereas the CEE is for vocational high school students who wish to enter colleges or universities of technology. First-year university and college students are usually required to take 3-4 hours of English every week.

Despite this significant exposure to English, Taiwanese students' English proficiency, based on the results of local and international English proficiency tests is far from satisfying. The TOEFL (Test of English as a Foreign Language) CBT (Computer-based Test) Score Data Summary from 2002-2006, 
provided by the Educational Testing Service (http://www.ets.org/Media/دj Research), shows Taiwanese students' scores ranked from the fourth-lowest to the seventh-lowest among the thirty-two countries in Asia. In another ETS (Educational Testing Service) survey conducted in conjunction with National Chengchi University in Taiwan, 32.3\% of 2755 Taiwanese university students among 20 universities who took the TOEFL IPT (Institutional Testing Program) function at the level of students in their third year of junior high or first year of high school (H. M. Huang, 2003). In 2004, according to the score data provided by the ETS, our TOEIC (Test of English for International Communication) scores ranked in bottom quarter among the 10 non-English speaking countries in Asia (X. Y. Yang, 2005). In 2006, as reported by the British Council, Taiwanese test-takers' scores on the IELTS (International English Language Testing System) were ranked 17th among the 20 countries that had the greatest number of test-takers (Z. Z. Chen \& Lin, 2007)(Cheng \& Lin, 2007). The LTTC (Language Testing and Training Center) contends that the local English proficiency test, the GEPT (General English Proficiency Test) elementary level, signifies competency equivalent to that of a junior high school graduate. However, the percentage of 9,527 college graduates at 86 technical colleges who passed the first stage of the GEPT elementary level, based on the LTTC score statistics in 2002 (http://www.itc.com.twi), is only $14.9 \%$.

This lack of proficiency is problematic because Taiwan is an island, the economy of which relies heavily on international trade. For example, the 3050th Executive Yuan Resolution asserted that international trade is the lifeblood of Taiwan's economic development. In 2006, our economic growth was $4.68 \%, 3.63 \%$ of which derived from trade with foreign nations. It is evident that international trade plays a vital role in the promotion of Taiwan's economic growth ("3050th Executive Yuan Resolution, Executive Yuan, Taiwan , 2007). Possessing a good knowledge of English has therefore become an integral part of conducting international business interactions.

Taiwan's government is aware of this, and is developing national English proficiency in order to be more competitive in global markets. In 1999, the Ministry of Education commissioned the Language Testing and Training Center to develop the General English Proficiency Test (GEPT) to "promote life-

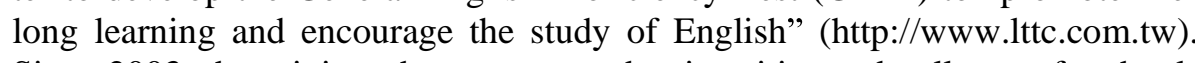
Since 2003, the ministry has encouraged universities and colleges of technology to set English thresholds for graduates to generate a level of proficiency 
sufficient to meet the anticipated needs of both domestic and international job markets

Some universities and colleges of technology have adopted the GEPT or other English proficiency tests such as TOEIC, TOEFL, IELTS, CSEPT (College Student English Proficiency Test) and school-designed tests as exit requirements. Some require students to pass the GEPT Intermediate or Elementary Level or school-designed proficiency. Others have set reward programs to encourage students to pass English proficiency tests by offering them financial incentives or exempting them from compulsory English classes.

English certification exit requirements, however, have met with opposition. Schools such as Ming Chuan University in Taipei (Y. F. Zhang, 2005) argue that universities and colleges are not cram schools. They do not advocate "teaching to the test", so they do not set English graduation thresholds. Instead, they require students to take more English-related classes to enhance their proficiency. Some English educators hold similar opinions. Liao (2004) is concerned that English proficiency requirements will force teachers to teach to the test because curricula will mirror exam content. Negative washback from the requirement will most likely manifest in teachers teaching to the test, students cramming for tests, and the narrowing of curricula. Liao suggests that students should be immersed in an English environment; setting proficiency test requirements for graduation is not a panacea. Su (2004) argues that setting thresholds requires a deeper investigation into issues such as whether schools' facilities, curricula, teachers' beliefs, and students' needs are in line with this decision. Some legislators (Mang, Zhang, \& Lin, 2003) have also expressed their objections.

\section{SETTING THE PURPOSE}

It is clear that the issues of whether it is appropriate to establish an exit requirement and of what doing so has effected have become a significant point of concern in Taiwan. According to Hughes (2003), washback is "a part of the impact a test may have on learners and teachers, on educational systems in general, and on society at large" (p.5). Bachman (1990) states that tests influence both education and society - tests are not developed and deployed in a "valuefree psychometric test-tube" (p. 279), and they are intended to fulfill the needs of an educational system or society. McNamara and Roever (2006) aver that, since tests can have widespread and unforeseen consequences, a language test 
that is psychometrically validated does not necessarily denote a test favorable for society. The researchers then propose the need to develop a social theory to assist test developers and researchers to better comprehend testing as a social practice.

In light of the importance of understanding the social impacts of test use, this paper synthesizes the opinions and surveys of a variety of stakeholders, including businesses, the government, administrators, educators and students, regarding the English certification exit requirement, as reported in major local newspapers during the last decade. It then constructs implications in terms of considerations for those involved in the establishment of the requirement and provides insights and suggestions for other stakeholders. By doing so, it is hoped that this study will be beneficial to those who are active in the fields of teaching, policy-making and test development.

\section{BUSINESS OPINIONS}

Taiwan's students at the tertiary-education level are often criticized by businesses for their inadequate English proficiency, and this has in part contributed to some universities establishing English certification exit requirements (L. X. Lin, 2001a).

At a conference, Wen Shi-Ren, the late vice-president of Inventec, a leading corporation in Taiwan's electronics and technology industry, suggested that universities establish exit requirements due to the concern that Taiwanese students' English proficiency will otherwise not reach an acceptable level before graduation, therefore resulting in reduced competitiveness when compared to their mainland counterparts (L. X. Lin, 2003).

Another well-known corporation requires that all its employees possess a certain level of English proficiency, and to ensure this, all potential employees must possess English certificates (L. X. Lin, 2005b). Chen Zong-Mou, the president of TSMC, which is the world's largest dedicated semiconductor foundry, claims that when facing the challenge of globalization, Taiwan's college students' in-common weakness is their English proficiency not being adequate for them to absorb innovations from other countries. As a result, they lack a well-developed capacity for internalization (Xu, 2006). Several other corporations in the banking, automotive, electrical engineering and semi-conductor industries also expressed the importance of good English as a component of performance evaluation and promotion. These industries adopt the TOEIC or self- 
developed tests to assess their employee's English proficiency for the purpose of promotion (Zheng, 2005).

In 2003, an online survey conducted by Pan-Asia Human Resources Bank and IBM indicated that nearly $98 \%$ of businesses screened their employees based mainly on their English proficiency. 97\% claimed that TOEFL, TOEIC and GEPT certificates were advantageous for job seekers, and salaries were determined according to their employees' English proficiency (Y. Z. Li, 2003). This survey also gave evidence that among 4,000 applicants, 68\% felt frustrated at job hunting because their English proficiency was insufficient, and 96\% contended that if they had earned English certificates such as the GEPT, they would experience better opportunities for gaining employment.

In 2004, according to the 240,000 job opportunities on their website, the 104 Human Resources Bank discovered that $53 \%$ of the listings required a certain level of foreign language proficiency, and, among that 53\%, 95\% required English proficiency. The survey also contended that since English is the basic international language for communication except for professionals such as international traders, overseas sales representatives, or technical document translators, many job responsibilities require only sufficient English proficiency to address daily or routine situations. Therefore, an intermediate level of English proficiency in reading and writing, the two skills most required in the workplace, is by far enough to handle the work ("The arrival of globalization: English proficiency a must at workplace", 2004).

Due to the trend of globalization, in 2005, one local bank included the GEPT intermediate certificate as a prerequisite requirement for those newly university/college graduates wishing to apply for employment as tellers. As compared to the tremendous number of applicants the bank received in the past, when potential employees took internally-developed English tests and certificates were not a necessity, the number of applicants dropped to 296. That decrease in the number of applicants indicates a significant discrepancy between the English proficiency of the workforce and the proficiency level businesses demand of their employees (Shao, 2005). The certificate requirement has prevented the application of a large number of college graduates. In a similar case, to decrease the overwhelming number of applications (as many as 8,000), China Airlines proposed that all applicants hold TOEIC certificates to be considered for employment (Z. Y. Wang, 2004).

A 2007 needs analysis of Taiwanese employees' English proficiency jointly conducted by the Chinese Human Resources Management Association 
and ETS (Educational Testing Service) stated that $50 \%$ of the 526 businesses investigated in Taiwan (including non-profit organizations such as schools and government departments) utilize English proficiency tests as a recruitment and promotion criterion. 43\% develop their own English tests, 29\% adopt the TOEIC, and 15\% use the GEPT to assess their employees' level of English proficiency. Scores ranging from 405 to 900 on the TOEIC are required for newly-hired employees, junior supervisory managers, or senior overseas supervisors (X. W. Wang, 2007). In another survey on a similar topic of needs analysis of Taiwanese employees' English proficiency conducted by $104 \mathrm{Hu}-$ man Resource Bank reported that among the 478 questionnaires, $49 \%$ of local businesses adopt the GEPT to assess applicants' English proficiency, while the TOEIC is favored by foreign corporations for its international recognition. This survey also revealed that $85 \%$ of businesses with more than 250 employees screened applicants' resumes by their scores on the TOEFL, TOEIC or GEPT (X. Y. Yang, 2005).

\section{Implications}

In light of the reports and surveys in the press, it is undeniable that possessing an acceptable level of English proficiency is an advantage for new university/college graduates when seeking employment. An English certificate is not only beneficial for job hunting but also leads to better opportunities for promotion or higher salaries. Therefore, it is necessary to set certification requirements to help students attain an acceptable level of English proficiency for better employment opportunities.

As reported above, as many as half of all businesses require the use of English in the workplace, and their standard for English proficiency falls in the range of the intermediate level (either GEPT intermediate level or at least 405 on the TOEIC). The other half of all businesses do not necessarily require English in the workplace. The implication here is that different standards of requirements should be established for different majors. For career paths that involve a greater understanding of English to facilitate work performance, such as business-related majors, a higher standard of test scores should be established as a graduation requirement. For industries that do not demand a higher level of English proficiency, the requirement can be set at the level of understanding the basic skills of English. 
The TOEIC and the GEPT are two predominant tests favored by business corporations. To address their needs, students should be provided with information, instruction and practice in class with regard to what and how to study and prepare to be more competitive in the job market.

However, it should be noted that nearly $50 \%$ of businesses evaluate their potential employees' English proficiency with tests they themselves develop. This implies that it is as essential to ensure college/university graduates have English proficiency sufficient in the four skills, in order for them to successfully pass tests given by potential employers, as it is to assist them in earning English certificates.

Another concern is whether schools with exit requirements have actually carried out their policy that students are not able to graduate if they do not pass English certification tests. The answer seems to be negative from the case of one bank's recruitment of newly graduates as tellers reported above. The implication of that report is that the number of college/university graduates who hold certificates that meet the standards of businesses are a minority. The requirement may sound like false advertising if there are ways to get around the requirement instead of actually passing the test. If the requirement is set so that students must reach a certain level of proficiency and receive a certain score on a test, all other remedial or supportive measures must evaluate the students to the same level of achievement.

\section{GOVERNMENTAL OPINIONS}

Ma Ying-Jiu, the former mayor of Taipei, suggested that university students should not be allowed to graduate if their proficiency in both Chinese and English is not satisfactory, because Taiwan's competitiveness lies in students' being proficient in both languages (R. Y. Chen \& Han, 2001). The former Minister of Education, Tzen Zhi-Lang, called for the enhancement of university students' basic English proficiency and offered more funding to help achieve that goal. He also required interested parties to investigate whether it is appropriate to set graduation requirements for English. However, he suggested that no single criterion be established as a graduation requirement so that students will benefit from learning through a variety of approaches (R. Y. Chen \& Han, 2001).

Schools are advised to adopt varied criteria to meet the needs and proficiency of students, and student-implemented comparison of their own profi- 
ciency can be used as one criterion for graduation requirements to evaluate whether progress has been achieved. Exit requirements for English are not discouraged by the Ministry of Education, but supportive measures should be provided so that students won't be impelled to kill themselves to meet the requirement (R. Y. Chen \& Han, 2001).

Another former Minister of Education, Huang Rong-Cun, recommended that English graduation requirements be established to scrutinize and evaluate whether students attain the English proficiency they are supposed to reach by the time they graduate (H. J. Yang, 2003).

The current Minister, Du Zheng-Sheng, announced in 2004 that a priority goal of the four major educational policy pivot points for 2005-2007 is to have $50 \%$ of students at universities and colleges of technology achieve an English proficiency equivalent to General English Proficiency Test (GEPT) Intermediate and Elementary Levels, respectively, by 2007. In order to reach that goal, the Ministry of Education has decided to allocate funding and grants based on the percentage of students who hold English proficiency test certificates (Hang, 2004). This is supposed to generate a $10 \%$ growth each year in the number of English certificates; that is, to $30 \%$ in $2005,40 \%$ in 2006, and the final goal of $50 \%$ in 2007.

It can be seen that setting English certification requirement has transformed from a recommendation to a must-do educational policy. Unfortunately, in 2006, many technical colleges were not able to reach this goal. Even more troubling, students' pass rate on the GEPT elementary level at a significant number of technical colleges was less than $10 \%$, and many schools had even fewer students who earned certificates. The majority of technical colleges did not reach the expected goal of a $30 \%$ pass rate (Jiang, 2006).

\section{Implications}

It goes without saying that the government hopes to enhance college students' English proficiency by encouraging universities/colleges to establish English certification exit requirements. An expected goal of annual growth in the pass rate has also been set and a considerable sum of funding, equivalent to $\$ 3,000,000$ US, was budgeted to encourage the institutions to achieve accountability. However, some schools stated that it is difficult to improve students' English proficiency to such a large extent, since their skills were quite poor when they were in vocational high schools (Jiang, 2006). In the literature, 
there were a number of examples where the government attempted to utilize tests to change curricula or promote learning outcomes (Cheng, 2004; L. Qi, 2005; Shohamy, Donitsa-Schmidt, \& Ferman, 1996), but these scenarios were unsuccessful because other factors such as educational systems (L. Qi, 2005) and educators' teaching beliefs (Cheng, 2004) also play an important role in the success or failure of innovation. In Taiwan, the government chose to use English certification tests to enhance students' proficiency, but tests are not a cured-all medication, and other supportive measures should be implemented. As a result, as suggested by some educators, curricula for college students should be established to match their level. Different criteria tailored to college students' English proficiency level should also be put into practice (Jiang, 2006). In light of this, students' English proficiency must be evaluated when they first enter college, and a reasonable goal they are likely to achieve must be established so that it won't worsen the discrepancy between the government's goal and what students can realistically attain.

Another concern is that if the GEPT elementary level is, in fact (as reported by its developer, LTTC), equivalent to the English proficiency of a junior high school student, why is the pass rate of college students for this level so low, as stated above? Two things need to be investigated. First, the LTTC needs to conduct more research to determine whether the GEPT elementary level is truly equivalent to a junior high school student's English proficiency. Then, curricula should be designed for college students with the utmost care, including additional number of English classes and suitable lesson content constructed according to both their proficiency level and needs.

\section{ADMINISTRATORS' OPINIONS}

In order to enhance students' English proficiency, increase their competitiveness in the job market, address the policy of the Ministry of Education and meet the trend of globalization, an increasing number of universities and colleges have established graduation requirements for English (L. W. Chen, 2004; R. Y. Chen, 2001; Jiang, 2002; L. X. Lin, 2001a; L. X. Lin, 2005a; Y. T. Lin, 2002; Y. T. Lin \& Meng, 2004; Z. C. Lin, 2007; Liu, 2004; G. H. Yang, 2003; Zhang, 2004, 2007; Zhou, 2007; Zhu, 2005b, 2006, 2007). Many schools utilize the GEPT, TOEIC, IELTS, TOEFL or school-developed tests to assess proficiency and require that students reach a certain score or level in order to graduate. If students are not able to meet the requirements, they are required to 
take extra remedial or intensive English classes. To help their students meet the requirements, some schools offer additional English classes and have expanded the offering of English classes from the first year to the third or final year. Others offer test-preparation or remedial classes (Y. T. Lin, 2002; Z. Y. Wang, 2004; Xue, 2007; J. H. Zhang, 2005; Zhou, 2007). Some have established zones where students are provided with an environment conducive to language learning. In these zones, students do online test-related practice and English readings, listen to audio versions of English magazines, or watch English-medium programs or movies. Some schools offer reimbursement of administration fees (S. L. Lin, 2005; Meng, 2004). Other schools exempt students who have earned certificates from compulsory English classes (L. W. Chen, 2004; Zhu, 2005b). Still others have first-year students take a placement test to stream them into groups based on their levels of English proficiency (Y. Z. Li, 2001; L. X. Lin, 2001b; Zhu, 2005a).

\section{Implications}

Many supportive measures, as shown above, have been implemented to assist students to both enhance their English proficiency and pass English certification tests. With these measures in place, it can be expected that the number of students earning certificates is supposed to increase. But why is the pass rate so low, as demonstrated in the previous section? More research needs to be conducted as to what each school has actually done to assist students to pass tests, including the curricula, educational resources, and facilities. Additionally, since the Ministry of Education distributes funding and evaluates accountability based on how well schools have promoted English certification exit requirements (Liu, 2004), does that favor high-ranking schools, since they already have better students and it is easier for their students to receive certificates? Do low-ranking schools have a harder time receiving funds because of their students' poor performance? Finally, providing funding for extra English classes or additional educational resources is definitely beneficial for the promotion of students' learning. However, the quantity of English classes is as essential as the quality. As stated in the previous section, curricula and lesson content must be constructed to meet the needs and level of students so that their motivation to learn English can be improved and the learning outcome will be satisfactory. 
Pan, Test Impact: English Certification 129

\section{EDUCATORS' OPINIONS}

English certification exit requirements encounter both supporting and opposing viewpoints from English teachers and educators. Those who are in favor of the policy claim that it will enhance students' proficiency (Lai, 2003), while opponents contend that it will lead to teaching to the test, studying for the test, and will inhibit creative learning, or learning from various approaches, i.e., cramming, which is often criticized when utilized in high school education, which might occur in college education as well (Cohen, 1994; E. Z. Wu, 2004; Q. X. Wu, 2001; Q. X. Wu, 2003, 2005; Zhou, 2001).

Most of these reports from educators' perspectives are concerned about the possible negative washback brought about by the requirement. For example, are tests the sole means for helping students improve their English? Learning shouldn't be manipulated by tests; instead, students should be encouraged to develop creative thinking by giving them freedom to read, to think, and to learn. The requirement promoted by the government will make the government become the best sales representative for cram schools, which profit from helping people earn certificates. Rather than using tests as a means to enhance students' English proficiency, it might be more beneficial for students to provide more books and materials in the library.

Another concern is whether a satisfactory score on the English certification test truly demonstrates one's sufficient English performance at the time of schooling. It is advised that schools play a key role in enhancing students' English proficiency, and they should have comprehensive and well-rounded curricula (J. Xiao, 2003). For example, the first three years of university education should focus on the development of a solid foundation of English skills in students, and subsequently they can prepare for English certification tests. Test scores should only be treated as reference points for evaluation; those who receive higher scores do not necessarily speak English well (M. W. Xiao, 2007).

\section{Implications}

Like other Asian areas, such as China (L. Qi, 2004), Hong Kong (Cheng, 2005; Fullilove, 1992), and Japan (Watanabe, 2004), in Taiwan, education is test-oriented. To put it differently, tests are a major determinant of course design and classroom practices, especially for junior and senior high schools. In 
Taiwan, many educational researchers and teachers note the phenomenon of negative washback effects brought about by the BCET (Basic Competency English Proficiency Test), a high school admissions test for junior high school students and the JCEE (Joint College Entrance Examination), a university/college admissions test for high school students. An example of one such claim of negative washback effect is Chou's (2002) contention that the BCET has resulted in students being overloaded with difficult preparatory materials and having to go to cram schools to stay abreast of classwork.

Another example is Tang's (1993) study on the JCEE, in which he contended that the previous test formats have contributed to aberrant English teaching and learning in Taiwan that focuses primarily on linguistic knowledge and mechanical drills while ignoring developing students' communicative competence. More research needs to be conducted to investigate if English certification exit requirements will bring "teaching to the test" to higher education as it has to junior and senior high schools, or if the requirement will rather act as an impetus to push students to work harder on learning English.

\section{STUDENTS' OPINIONS}

Different student viewpoints and attitudes regarding the exit requirement have been reported in the press. According to a survey of 1162 northern university students conducted by a college student association, $63 \%$ approve of the exit requirements for English because they feel their proficiency has regressed due to a lack of attention since they entered college. Although they need to read textbooks written in English in their various disciplines, the language used in the text has little application to daily life. Utilizing the GEPT as an exit requirement can not only push them to study English, but the GEPT certificate is also beneficial when they seek employment after graduation. However, more than $50 \%$ are concerned about their ability to pass the test, and around $25 \%$ fear that this policy may lead to cramming. The survey also indicated that $41 \%$ of college students believe their weakest skill is speaking, while $28 \%$ responded writing and $24 \%$ cited listening. As many as $53 \%$ of the surveyed students were not satisfied with the English courses offered at their schools, and they would rather study on their own or listen to radio broadcasts or take extra lessons at cram schools to help them pass the test. Students were also quite frank in relating that the time they spend on English is negligible (Y. J. Huang, 2004). The majority of the students find the requirement reasonable 
and do not resist it because earning certificates before graduation will be beneficial for either their future employment or further studies (Shen, 2004).

In another report that addresses the impact of the exit requirement, some students make greater efforts to study English because they are afraid they might not be able to graduate if they do not pass the test ("Students crazy for GEPT at universities", 2005). However, students complain that preventing them from graduating because of a failure to pass the English certification test is unfair if they have passed the compulsory English courses. Some feel an intense hopelessness; no matter how many times they take the certification test, they still cannot pass (Cai, 2006). In a similar case, students had a very strong negative reaction when nearly $60 \%$ of them could not graduate on time because they couldn't pass English certification tests (H. S. Lin, 2007). Another complaint is that the school did not offer sufficient or appropriate curricula to enhance students' listening skills, since $90 \%$ of them did not pass the GEPT practice test because of their poor listening proficiency (Zhang, 2003). The financial burden resulting from taking lessons at cram schools to pass the test is yet another negative washback brought about by the requirement. Some students in graduate school lamented the fact that they must spend quite a considerable sum of money on a cram school just to pass the English certification test (Jiang, 2005). Still other students don't think schools should demand that they take certification tests because of the expensive administration fees for many current tests. The tuition fees are especially high at the moment, and the requirement for students to take tests actually imposes more burden on them (Shen, 2004).

Whether the exit requirement can really help enhance students' English proficiency is another concern, because students who are not able to pass the test are actually given a "back-door" option to meet the requirement; that is, they can take extra classes if they cannot pass the test. Because of this, it is questionable whether these students can pass the real English certification test. If they cannot, it is quite meaningless for schools to offer back-door options just to assist students to graduate (M. W. Xiao, 2007; Y. K. Yang, 2006).

\section{Implications}

In reviewing students' opinions, several concerns arise that must be addressed in order to make this policy beneficial to them. First, in order to help students to pass the English certification test, test-preparatory classes or testrelated instruction in regular English class need to be offered so that students 
will have greater familiarization with the test and a clear direction as to what and how to prepare for it. This way, students may not need to seek assistance from cram schools. If sufficient resources are offered at their schools, this will alleviate the financial burden created by cram schools.

Second, definite teaching objectives for English classes need to be set so that teachers have a clear goal regarding the level of English proficiency students should achieve in class. With the implementation of these teaching objectives, students who are able to pass the English class will more likely be able to pass the test. Although the ability of students to pass the test involves a number of factors, such as motivation, proficiency, effort and even luck, a matching of curricula and what is evaluated on the test may be a good means to create "win-win" results for both teachers and students.

Third, English teachers may have to work on how to enhance students' motivation to learn English in class. If lesson content or teaching methodology can be adapted to meet their interests, needs, and level of English proficiency, students may be more interested in learning English, and learning outcomes will, accordingly, much improve. Finally, the decision to offer "back-door" options to those who cannot pass the test depends on value judgments. Schools must consider appropriate cutoff criteria to define the level of most students. For example, the basic proficiency of students must be investigated so the exit requirement will be appropriate to the students' level, making it neither too easy nor too hard for students to meet the requirement.

\section{CONCLUSIONS AND SUGGESTIONS}

It is apparent from a review of the media-reported viewpoints of different stakeholders regarding the English certification exit requirement that it is difficult to reach an agreement that will satisfy all needs to attain the enhancement of students' English proficiency. The exit requirement has brought about both positive and negative washback. On the positive side, the government has had a significant impact on college English education by allocating a considerable amount of funding to increase the pass rate of college students who earn certificates. Additional English classes, expansion of the English course requirements, and building or purchasing of more educational resources and facilities have been undertaken by schools to help students improve their English, thus raising the pass rate. Students' scores reveal what skills must be improved so that educators can design more effective curricula or lesson plans to meet stu- 
dents' needs. Students are encouraged to take the study of English more seriously because they might not be able to graduate if they do not pass the test.

On the negative side, teachers are concerned that the requirement might lead to teaching to the test, although that is an issue that requires much more research before any definitive conclusions can be drawn. The requirement may exert undue pressure on students because of the concern that they may not be able to graduate if they do not pass the test. In addition, some students are concerned that the material assessed on tests used as exit requirements is not applicable to daily life or real-world situations. Many students have a justifiable complaint that they should be able to pass the test if they are able to pass English class, and that complaint warrants further investigation.

It goes without saying that the success of the requirement policy lies in the collaboration of various interested parties, including the government, businesses, school administrators, test-developers, educators, and students. In terms of the government, in order to attain the goal of the policy, which requires $50 \%$ of students reaching a proficiency equivalent to that of the GEPT elementary or intermediate level by 2007 , utilizing the test certification exit requirement and providing funding to enrich curricula and resources are positive steps; but the problem may need to be addressed at a more basic level. In other words, educators must facilitate the process of building students a solid foundation of basic skills from the beginning of their English learning process, instead of requiring college students to reach a particular level of proficiency within a certain timeframe without considering their original proficiency when they enter colleges/universities.

As for businesses, considering that Taiwan is an island that requires English as a medium of communication with the international world for the purpose of business interactions, it is advised that they require English certification of their applicants and employees. With this requirement in place, college students will pay more attention to English because of better future opportunities in the workplace.

For test-developers, it is necessary to conduct validity research regarding their can-do lists or what level of proficiency test-takers will possess when they reach a certain level or score so that test-users have clear and objective criteria regarding what to adopt when establishing appropriate exit requirements to match the level of their students' English proficiency.

For school administrators, providing funding for extra English classes or additional educational resources is definitely beneficial for the promotion of 
students' learning. However, curricula must be constructed to meet the needs and proficiency levels of students so that their motivation to learn English can be improved and the learning outcomes will be satisfactory. For educators, if it is a trend to set the English certification exit requirement, teachers need to help students pass the test and earn the certificate. To facilitate positive washback from tests, teachers need to make efforts to combine their lesson content with what is covered on tests so that teaching to the test will not occur. As for students, they must cultivate the concept of autonomous learning and strive to study English after class if they want to pass the test and receive the certificate. All in all, although reaching the goal may be difficult, receiving the greatest benefits of English certification exit requirements involves the active participation and diligence of everyone involved.

\section{REFERENCES}

3050th Executive Yuan Resolution, Executive Yuan, Taiwan. 2007. Retrieved December 28, 2007, from ihttp://Lww.ey.gov.tw/ct.asp?XItem=30670\&ctNode $=24 \& m p=11$

The Arrival of Globalization: English Proficiency a Must at Workplace. 2004. Retrieved December 26, 2007, from inttp://www.104.com.tw/cfdocs/2000/pressroom/104news931008.htm

Bachman, L. F. 1990. Fundamental Considerations in Language Testing. Oxford: Oxford University Press.

Cai, Z. G. 2006. English Requirement Keeps 44 from Graduating. So Depressing! China Times.

Chen, L. W. 2004. Poor English Skills Prevent Graduation. China Times.

Chen, R. Y. 2001. Universities Set Requirements to Improve Students' English Proficiency. China Times.

Chen, R. Y., \& Han, X. Y. 2001. Ma Ying-Jiu: Save University Students' English Proficiency. China Times.

Chen, Z. Z., \& Lin, J. H. 2007. IELTS: Our Poor English Ranks in Bottom Quarter. China Times. 
Cheng, L. 2004. The Washback Effect of a Public Examination Change on Teachers' Perceptions Toward Their Classroom Teaching. In L. Cheng, Watanabe, Y., Curtis, A. (Eds.). Washback in Language Testing: Research Contexts and Methods (Pp. 147-170). Mahwah, New Jersey: Lawrence Erlbaum Associates, Publishers.

Cheng, L. 2005. Changing Language Teaching Through Language Testing: A Washback Study. Cambridge: Cambridge University Press.

Chou, C. T. 2002. Keep English Teaching Practices Simple. United Daily News.

Cohen, L. a. M., L. 1994. Research Methods in Education (4th ed.). London: Rutledge.

Fullilove, J. 1992. The Tail that Wags. Institute of Language in Education Journal. 9:131-147.

Hang, G. D. 2004. Du Zheng-Sheng: Enhancement of Students' English Proficiency One of the Educational Policies for the Next Four Years. China Times.

Huang, H. M. 2003. Nearly One Third of University Students' TOEFL Scores Equivalent to Junior High School Students' English Proficiency. Central News Agency.

Huang, Y. J. 2004. Exit Requirements Worry Students. Liberty Times. Retrieved December 25, 2007, from 'http://www.libertytimes.com.tw/2004/new/oct/17/today-life9.htom

Hughes, A. 2003. Testing for Language Teachers (2nd ed.). Cambridge: Cambridge University Press.

Jiang, Z. Q. 2002. Poor English? Be careful-You Won't be Able to Graduate. China Times.

Jiang, Z. Q. 2005. Cramming to Meet Standards Hard on Students' Wallets. China Times.

Jiang, Z. Q. 2006. Most Fail GEPT Despite Heavy MOE Financing. China Times . 
Lai, Z. Q. 2003. Concerned by University Students' English Level, Educators Support Certification Tests. Min Sheng Daily.

Li, Y. Z. 2001. Freshmen Streamed According to English Test Scores. China Times Express.

Li, Y. Z. 2003. Poor English not Acceptable to $98 \%$ of Businesses. China Times Express.

Liao, P. 2004. The Effects of the GEPT on College English Teaching. Retrieved January 1, 2007, from http://home pchome.com.tw/showbiz/posenliao/page/page 5 -011.htm.

Lin, H. S. 2007. GEPT Colors NPUST Graduation. China Times.

Lin, L. X. 2001a. Universities Set English Proficiency Requirements. Min Sheng Daily.

Lin, L. X. 2001b. Freshmen Streamed According to English Test Scores. Min Sheng Daily.

Lin, L. X. 2003. Concern Over Students' Insufficient Abilities: Businesses Suggest Graduation Thresholds Set for Computer and English. Min Sheng Daily.

Lin, L. X. 2005a. Universities Address Workplace English Needs. Min Sheng Daily).

Lin, L. X. 2005b. Internationalization at Workplace: Local Industry Sets Strict English Proficiency Requirement. Min Sheng Daily.

Lin, S. L. 2005. Strong Medicine Cures Students' English Ills. United Daily News.

Lin, Y. T. 2002. National Taiwan University Freshmen Requires 550 on TOEFL. United Daily News.

Lin, Y. T., \& Meng, X. J. 2004. More than 30 Universities Set GEPT as Graduation Thresholds. United Daily News.

Lin, Z. C. 2007. Soochow Graduates Must Pass GEPT High-Intermediate Level. China Times. 
Liu, J. Y. 2004. Foreign Language Majors Must Pass Intermediate GEPT to Graduate. United Daily Evening News.

Mang, X. J., Zhang, J. H., \& Lin, X. F. 2003. Legislators: The General English Proficiency Test Cannot be Set as the Graduation Threshold. United Daily News

McNamara, T., \& Roever, C. 2006. Language Testing: The Social Dimension. Oxford: Blackwell.

Meng, X. J. 2004. Schools Throw Money into English-learning Clinic. United Daily News.

Qi, L. 2004. Has a High-Stakes Test Produced the Intended Changes? In L. Cheng, Y. Watanabe \& A. Curtis (Eds.). Washback in Language Testing. Research Contexts and Methods, pp. 147-170. Mahwah, NJ: Lawrence Erlbaum Associates.

Qi, L. 2005. Stakeholders' Conflicting Aims Undermine the Washback Function of a High-Stakes Test. Language Testing. 22(2):142-173.

Shao, C. X. 2005. English Requirements Lead to Fewer Applicants. Commercial Times.

Shen, H. Y. 2004. Several Schools Set GEPT as Graduation Thresholds. Liberty Times. Retrieved December 27, 2007, from htttp://www libertytimes.com.tw/2004/new/sep/9/today-life 7.htm

Shohamy, E., Donitsa-Schmidt, S., \& Ferman, I. 1996. Test Impact Revisited: Washback Effect Over Time. Language Testing. 13:298-317.

Students Crazy for GEPT at Universities. 2005. United Daily News.

Su, S. W. 2004. Considerations on the Threshold Establishment of English Proficiency Tests at Colleges of Technology [Electronic Version]. Electronic Journal of English Education, 11 from

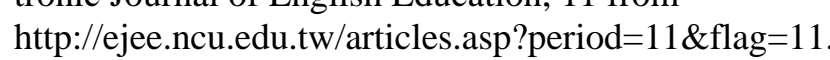

Tang, T. C. 1993. University English Exams: Review and Suggestions. Paper Presented at the The First International Symposium on English Teaching Taipei. 
Wang, X. W. 2007. 2007: Taiwan's Industries Need Standard for Employees' English Proficiency. Retrieved December 27, 2007, from 'http://tw.myblog.yahoo.com/benwangblog/article?mid=52\&prev=54 \&next $=51$

Wang, Z. Y. 2004. English Tests at Orientation. United Daily News.

Watanabe, Y. 2004. Teacher Factors Mediating Washback. In L. Cheng, Y. Watanabe \& A. Curtis (Eds.). Washback in Language Testing: Research Contexts and Methods, pp. 129-146). Mahwah, New Jersey: Lawrence Erlbaum Associates, Publishers.

Wu, E. Z. 2004. English Certification Exit Requirement: Masters of English Improve Even More. United Daily News.

Wu, Q. X. 2001. Test-Driven English Learning has Negative Effects, Pushing People Away from Life-Long Learning. United Daily News.

Wu, Q. X. 2003. Test-Based Learning no Blessing for Tertiary Education. United Daily News.

Wu, Q. X. 2005. Does Government Suffer From GEPT Hysteria? United Daily News.

Xiao, J. 2003. GEPT Scores: to Draw a Snake and Add Feet to It. United Daily News.

Xiao, M. W. 2007. TOEIC Used as Employment Recruitment Standard. Commercial Times.

Xu, J. J. 2006 Chen Says Students Lack Global View. United Daily News.

Xue, H. Y. 2007. Save Poor English, Contributed to Enthusiastically by Technical Colleges. United Daily News.

Yang, G. H. 2003. A Number of Schools Set Graduation Thresholds to Enhance Students' Proficiency. China Times.

Yang, H. J. 2003. Huang, Zong-Cun: Suggests Setting Graduation Thresholds for English. United Evening News.

Yang, X. Y. 2005. Taiwan Ranks in Last Fourth on IEITS Scores in Asia. China Times Express. 
Yang, Y. K. 2006. English Certification Exit Requirement? Back door! Liberty Times Retrieved December 26, 2007, from 'http://Www.libertytimes.com.tw/2006/new/jan/1/today_o10.htm

Zhang, J. H. 2003. Students: Lack of Support Caused Low GEPT Listening Scores. United Daily News.

Zhang, J. H. 2004. Graduation Thresholds for English a Trend. United Daily News.

Zhang, J. H. 2005. Fight for English. United Daily News.

Zhang, J. H. 2007. Internationalization: 44 Schools Offer Dual Degree Program. United Daily News.

Zhang, Y. F. 2005. The General English Proficiency Test as a Graduation Threshold: The High-Intermediate Level for National Taiwan University and National Chengchi University. United Daily News

Zheng, G. W. 2005. Hot issue: Don't understand English? Get ready to be kicked out. Commercial Times.

Zhou, S. H. 2001. Can the GEPT be Used as the Graduation Threshold? China times.

Zhou, S. H. 2007. CTUST Wins Second Best Proposal Grant. Commercial Times.

Zhu, W. Z. 2005a. Freshmen Tested for Their Chinese and English: Good for Exempting from English Classes, Bad for Remedial Classes. China Times Express.

Zhu, W. Z. 2005b, November 28. Passing English Certification Test to Register for Entrance Exam or Graduation. China Times.

Zhu, W. Z. 2006. 7 Universities: Not Able to Graduate Because of GEPT failure. China Times.

Zhu, W. Z. 2007. GEPT Failure Prevents Graduation. China Times. 